
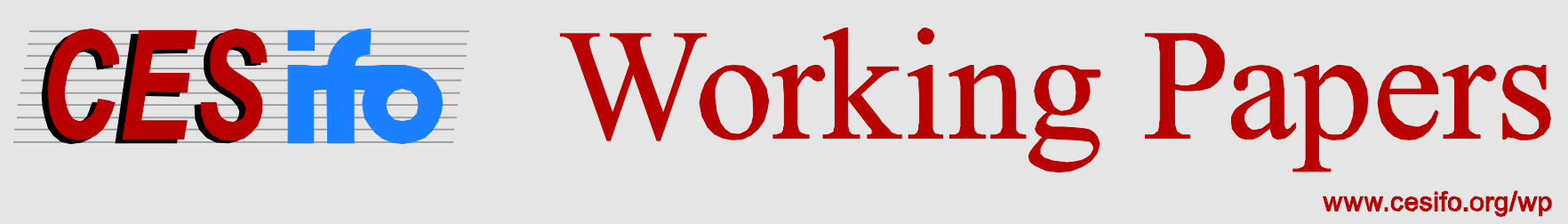

\title{
Monetary Policy Crisis Management as a Threat to Economic Order
}

\author{
Andreas Freytag \\ Gunther Schnabl
}

\author{
CESIFO WORKING PAPER NO. 6363 \\ CATEGORY 7: MONETARY POLICY AND INTERNATIONAL FinANCE \\ FEBRUARY 2017
}

An electronic version of the paper may be downloaded

- from the SSRN website:

- from the RePEc website:

- from the CESifo website:

WwW.SSRN.com

Www.RePEc.org

www.CESifo-group.org/wp 


\title{
Monetary Policy Crisis Management as a Threat to Economic Order
}

\begin{abstract}
The paper analyses the effects of the monetary policy crisis management of the European Central Bank on the economic order of Germany. It is argued that in post-war Europe the German social market economy as designed by Eucken (1952) and Müller-Armack (1966) has been a core element of growth, welfare, social cohesion and political stability in Germany and Europe as a whole. It is shown that the monetary policy rescue measures of the European Central Bank have undermined the constitutive principles of the German social market economy, what has considerably contributed to the erosion of (productivity) growth and welfare in Germany and Europe. As the outcome is crumbling social cohesion and growing political instability, a timely exit from ultra-expansionary monetary policy is postulated.
\end{abstract}

JEL-Codes: B200, E140, B250.

Keywords: economic order, social market economy, Soziale Marktwirtschaft, Germany, Walter Eucken, Alfred Müller-Armack, monetary policy, crisis management.

Andreas Freytag

Friedrich-Schiller-University Jena

\& Stellenbosch University

Jena / Germany

andreas.freytag@uni-jena.de

\author{
Gunther Schnabl* \\ University of Leipzig \\ Leipzig / Germany \\ schnabl@wifa.uni-leipzig.de
}

*corresponding author

February 16, 2017

We thank the participants of the 2016 Leipzig Conference on „Zero Interest Rate Policy and Economic Order“ for very helpful comments. 


\section{Introduction}

After seven years, the European sovereign debt and financial crisis is far from being solved. The general government debt levels in the European Monetary Union are in most member states close to record high levels and far beyond the 60\%-Maastricht benchmark. Unemployment in the Southern European member states is high, particularly among young people. The influence of vested interests, especially the financial industries, is remarkable. European banks have been able to privatize gains and socialize losses of the latest financial cycle, which has significantly contributed to the rise of public debt and the decline of credibility of market economies.

The political response to the crisis is best described as defensive, with reform agendas remaining widely untouched. As a consequence of the governments's reluctance to address the foremost problems (among them excessive expenditure obligations and labor market regulation) the European Central Bank (ECB) has been assigned a growing number of objectives. Besides its goal to achieve price stability (as defined in the Treaty on the Functioning of European Union), the ECB aims to ensure financial sector stability, to stimulate investment, to keep together the eurozone and to prevent unemployment via unconventional monetary policy.

Figure 1 one shows that short-term interest rates have declined to zero and the balance sheet of the ECB has grown to unprecedented levels. Trying to achieve several policy objectives with one instrument is a deviation from the Tinbergen (1952) rule, which postulates for each policy objective one policy instrument. Confronted with several goals, the ECB is facing a number of potential trade-offs, for instance between short-term and long-term financial market stability as well as between short-term and long-term growth.

The immense scale of monetary policy crisis management also raises the question of whether current monetary policy is putting the economic order at risk. The ECB's government debt purchasing program strongly reminds of quasi-fiscal financing via the money press (Deutsche Bundesbank 2016). Even more, from a German perspective, the unconventional monetary policy of the European Central Bank seems to put into question the working mechanism of the social market economy, which has been constituted in the post-war era by Walter Eucken (1952) and Alfred-Müller-Armack (1966).

We will discuss whether the current monetary policy of the European Central Bank is compatible with Germany's Social Market Economy (Soziale Marktwirtschaft) and is 
therefore in the interest of Germany and Europe as a whole. To develop our argument, we discuss the fundamental differences in concepts of economic policy making in Europe and introduce the core elements of Germany's post-war economic order. We will show that the unconventional monetary policy of the European Central Bank is in conflict with the constitutive principles of German economic order in specific and market economies in general.

This implies a clearly negative impact on growth and social cohesion in both Germany and its partner countries in the European (Monetary) Union. Therefore, the final section postulates a return towards market principles in Europe via the exit from ultra-expansionary monetary policy. This would enhance social cohesion in Europe in every single country and furthermore at a supranational level.

Figure 1: ECB Balance Sheet and Money Market Rate

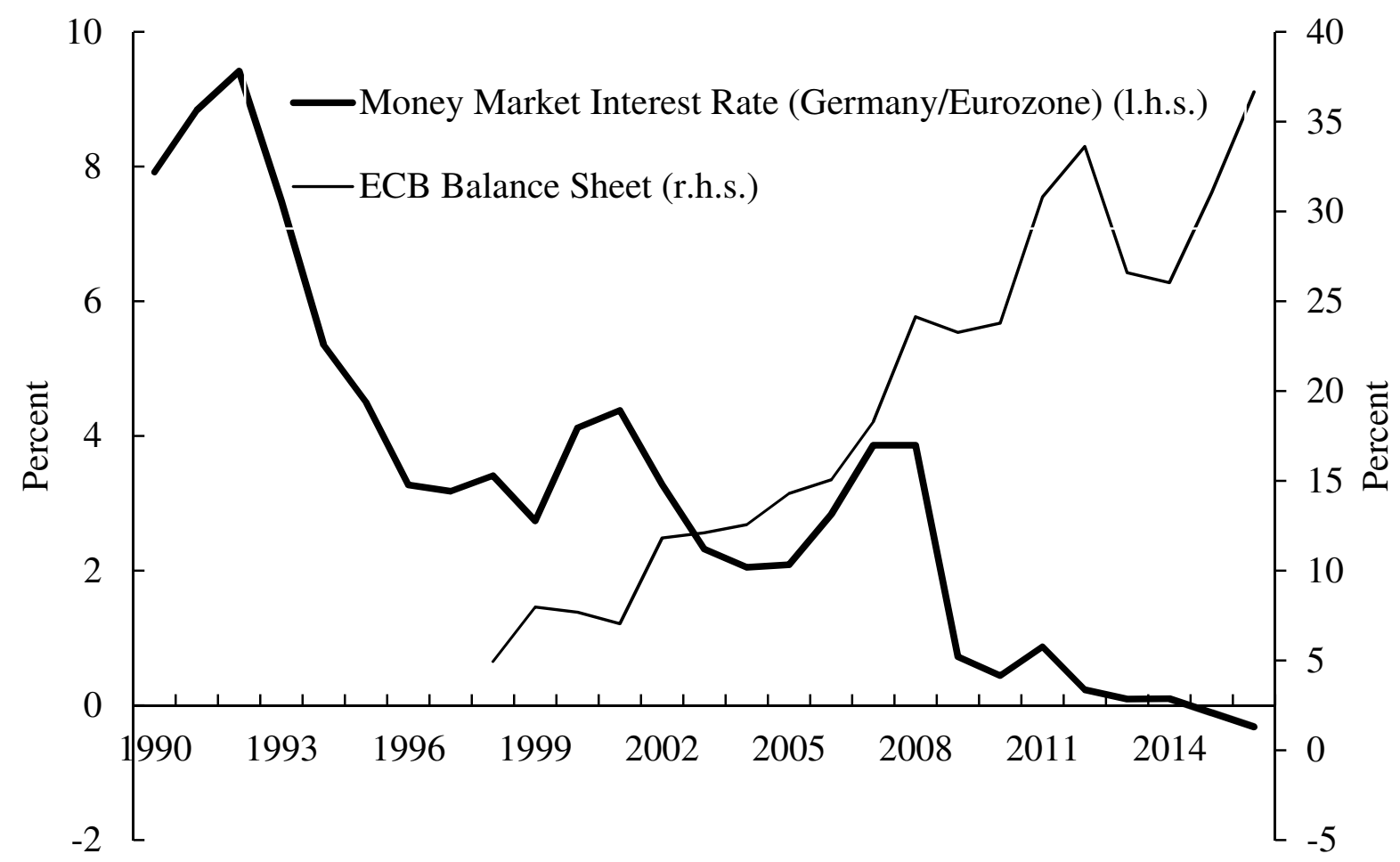

Source: IMF: IFS. Balance sheet as percent of GDP. Money market rate: until 1999 Germany. 


\section{Different Concepts of Economic Policy Making in Europe and the German "Social Market Economy"}

In general, the economic order of a country is rooted in institutional and cultural traditions and the country's value system. It organizes the division of labor among private agents as well as between markets and the state. At the best, the economic order cannot be changed at short notice, but is subject to gradual change. ${ }^{2}$ An economic order or governance structure comprises all realms of economic policy making, in particular monetary, fiscal, competition, industrial and social policy.

\subsection{Different Concepts of Economic Policy Making in Europe}

All post-war Western European countries were liberal market economies with a high and increasing degree of openness to trade, capital flows and labor movement. Nevertheless, there has been a broad variety of concepts of economic order and economic policy making with long traditions each. Northern European countries can be seen as monetarist, liberal economies which could afford themselves - because of high levels of productivity - generous welfare states. This has been similar in the United Kingdom and Ireland, which have less of a focus on social policy. In the southern European countries, there has been trust in state interventions and Keynesianism (Muresan 2014).

These differences also implied different growth models and different concepts of central banking. In Germany (and some smaller northern European countries such as Austria or the Netherlands) growth was based on comparatively high saving rates, high investment and export-driven growth. This growth model strongly depended on a price stability-oriented central bank, which ensured low real interest rates as a prerequisite for buoyant investment. Central bank independence (as in the case of the Deutsche Bundesbank) necessitated fiscal discipline, with the government financing expenditures via tax revenues.

In the southern and western parts of Europe, the growth models were oriented towards consumption and government expenditure, with the latter one being partially financed via inflation tax. Central banks were not independent, but subject to guidance by the

2 Until the late 1980s, the notion dominated that there was a common blueprint for all countries, called Washington consensus (Williamson 1990). During the 1990s, the view became common that one-size-fitsall-solutions are not adequate. With respect to monetary policy it was argued that the optimal policy regime is contingent on other elements of the economic order, e.g. the institutional setting or governance structure (Freytag 2002). 
governments. The resulting depreciations of the currencies (against the German mark) created an additional aggregated demand stimulus. For Germany and its smaller neighboring countries, these beggar-thy-neighbor policies were economically and politically acceptable, because they got access to the southern and western European markets, which helped to realize economies of scale in industrial production.

The upshot is, that growth rates of per-capita income in post-war Western Europe (in particular between the large countries Italy, France, United Kingdom and Germany) were strongly intertwined. The mutual interest in these different growth models was reflected in the smooth and continuous deepening of the European integration process. The Single European Act of 1986, which finalized the four freedoms - free movements of goods, services, labor and capital - can be seen as the crowning of this pan-European growth model. With Germany being the largest economy in Europe with a stable currency and a strong economy, the German economic order can be seen to have been in the center of European post-war growth dynamics.

\subsection{The German Social Market Economy}

Germany had chosen an economic order, which can be located between the Scandinavian and the Anglo-Saxon model. It was based on free exchange on markets, but also placed emphasis on redistribution and social justice. The name "Social Market Economy" indicates this blend. The German model of economic order was rooted in the experience of the late Weimar Republic's monopolization and cartelization and the inability of the democratic government to contain these trends. The failure of democracy had come along with a totalitarian government gaining control of the large monopolies, which led into a command-and-control economy. ${ }^{3}$ The approach of the Freiburg School of Law and Economics - also called Ordoliberalism or "Ordnungspolitik" - emphasized the importance of rules in economic policy making (see Eucken 1952, Miksch 1937 and Böhm 1950). The economic order was seen a set of rules agreed on by the citizens in consensus. There was a distinction between the rules of the game and the game itself. There are at least two reasons for accepting rules (Vanberg 2015): first, rules are a default option for individuals and collective bodies unable to forecast the future and to create solutions for all thinkable situations. Second, rules protect governments from the

\footnotetext{
3 This process was reflected by Hayek (1944) as "Road to Serfdom".
} 
influence of powerful interest groups seeking rents through regulation or forms of protection. By signaling adherence to rules, the government can discourage lobbies to invest into rentseeking activities.

The main principle of the German post-war economic order was the decentralized coordination on markets with the help of a functioning price system as opposed to subordination through a hierarchically centralized system with price controls. The state enforces rules, but is not a market participant. Other elements of this order comprised private property rights, liability, subsidiarity, rule of law, currency stability, freedom to contract and a longterm orientation of economic policy.

The economic order was based on individual responsibility, collectively supported by a set of social policies within a welfare state in line with the thoughts from the catholic social doctrine (Müller-Armack 1950/1982, Marx 2006). This doctrine emphasizes the individual responsibility on the one hand and the crucial role of entrepreneurs (as opposed to managers) on the other hand. Entrepreneurs strive not only for profits but also take responsibility for workers, their city and their region, and more generally for the society. In particular, the role of small and medium-sized enterprises (SMEs) and their owners' with their (in contrast to managers) long-term profit orientation contributes to the sustainability of business models.

Within a market-oriented framework socially undesired outcomes were to be corrected by public authorities. ${ }^{4}$ The Freiburg School emphasized the need to protect competition from cartelization and monopolization and developed a comprehensive competition law and competition policy. ${ }^{5}$ The essence of German Ordoliberalism was outlined by Eucken (1952) in form of eight constitutive and four regulative principles for a sound functioning of a social market economy. ${ }^{6}$ The ordering of the principles was only partly arbitrary; at least the placement of constitutive principle 1 and constitutive principle 8 respectively comes naturally:

Constitutive principle 1 is designed to ensure a functioning price mechanism based on perfect competition as the fundamental principle for market economies.

4 For more details see Starbatty (1984).

5 See for instance Kantzenbach 1966 und Hoppmann 1968.

6 Relying on principles for economic policy making is also found in other theories of economic policy making. New institutional economics argues that the rules of the game, regardless of being written or unwritten and of being created or have been spontaneously evolving, are relevant for the economic (and political) success of a society (North 1990). The literature on time consistency (Lucas 1976) and central bank independence put forward a similar argument on a more formal basis (Freytag 2002). 
Constitutive principle 2 stresses the primacy of a stable monetary order as crucial prerequisite for functioning market economies.

Constitutive principle 3 calls for open markets, where competition among a large number of (small) players works.

Constitutive principle 4 is private ownership, which was regarded as necessary to ensure incentives to strive for profits and thereby efficiency.

Constitutive principle 5 is the freedom of contract between individuals, which does not allow for market entry barriers, except for severe market failure.

Constitutive principle 6 is the liability principle; market participants who have responsibility are also liable for the consequences of their action.

Constitutive principle 7 is continuity of economic policy in the sense that erratic changes because of fiscal reasons or government changes are excluded.

Constitutive principle 8 points to the interdependence of order. All principles only enfold their full effectiveness, if they are simultaneously fulfilled.

The regulative principles aimed to correct undesired developments, which would possibly evolve within the free-market framework of the constitutive principles.

Regulative principle 1 called for an antitrust authority, which should control the market behavior of large private enterprises and ideally dissolve monopolies or prevent monopolies from emerging.

Regulative principle 2 stipulated redistribution via a progressive tax system.

Regulative principle 3 - i.e. the correction of (negative) externalities - was fitted already by then to issues of environment protection. The government was attributed the task to internalize negative external effects.

Regulative principle 4 targeted at the correction of anomalous developments in labor markets by regulation. Eucken (1952) thought of restrictions on the length of working hours, in particular for children and (by then) women. 


\section{Monetary Policy Rescue Measures as a Threat to the Economic Order}

The constitutive principles of Eucken (1952) were designed with respect to goods markets. The underlying assumption was that monetary policy is stability-oriented. Whereas today in goods markets the constitutive principles are - more or less - warranted, the monetary policy rescue measures of the European Central Bank seem to have toppled all constitutive principles via the detour of financial markets. In the following, Eucken's (1952) constitutive principles are matched with the impact of the ECB monetary policy measures on financial and goods markets.

Constitutive principle 1 was designed to ensure a functioning price mechanism based on perfect competition as the fundamental principle for market economies. Eucken (1952: 254291) regarded a decentralized market structure as a prerequisite for a well-functioning price system. $^{7}$ This fundamental principle made a strong statement against discretionary price distorting measures such as public subsidies, tariffs or direct price controls. Competition had to be preserved to sustain the functioning of the price mechanism. The interest rate was regarded as a core price in market economies, as changes in interest rates affect all other prices and thereby fundamentally change the structure of the whole economy. ${ }^{8}$ For this very reason undue credit expansion should not disturb the information function of prices. ${ }^{9}$

In contrast, the monetary policy of the European Central Bank has destroyed price determination on capital markets by nudging the short-term interest rate (via conventional monetary policy measures) and the long-term interest rates (via unconventional monetary policy measures, mostly outright government bond purchases) towards zero or even in negative territory. This has disturbed two main functions of the interest rates. First, the allocation function, which separates planned investment projects with high expected returns from planned investment projects of low expected returns. Second, the signaling function, which indicates the risk of default and therefore puts a limit on debt of highly indebted entities.

\footnotetext{
7 See also Hayek (1945) on the Use of Knowledge in the Society.

8 „Infolge ihrer allgemeinen Interdependenz üben alle einzelnen wirtschaftspolitischen Eingriffe Wirkungen auf den gesamten Wirtschaftsprozess aus. Wird etwa der Zins heruntermanipuliert, so wird hierdurch - wie oft nachgewiesen wurde - das Gesamtsystem der Preise und damit die ganze Lenkung des Wirtschaftsprozesses verändert“. (Eucken 1952: 254)

9 See Hayek (1931) on the role of too loose monetary policy for credit cycles and business cycle fluctuations.
} 
Due to excessive liquidity injections into capital markets, rising prices on stock and real estate markets are not necessarily indicating anymore high future returns of enterprises and real estate projects. Instead, they reflect the abundant availability of low-cost capital. The intended side effects of excessive monetary expansion in the form of hiking real estate prices or real wage repression has created incentives for price controls, for instance for rents (given fast rising real estate prices) or in form of minimum wages (given stagnating wage increases of even falling wages for newcomers in the labor market). ${ }^{10}$

Constitutive principle 2 stressed the primacy of a stable monetary order as a core prerequisite for the functioning of market economies. Eucken (1952) argued that a stable currency is the basis for a stable economic development, because he had observed in the past monetary instability being linked with volatile business cycles and thereby uncertainty. ${ }^{11} \mathrm{He}$ recommended an automatic regulation of money supply, as for instance ensured by a commodity-bundle standard and a $100 \%$ reserve requirement for banks at the central bank to prevent a discretionary use of monetary policy to serve partial interests.

In contrast to the ideals of Eucken (1952) both the German mark as well as the euro were set up as fiat currencies, with money creation being delinked from any real value. ${ }^{12}$ Given that since the mid 1980s the link between monetary policy decisions and consumer price inflation became increasingly weak (see for instance Gertler and Hofmann 2016), this opened the central banks the opportunity to pursue additional goals such as financial market stabilization and/or government financing without interfering with inflation targets as rule-based monetary policy approaches (Schnabl 2016).

The asymmetric interest path ${ }^{13}$ of the European Central Bank as well as the unconventional monetary policy measures, as shown in Figure 1, have come along with a historically stable

10 Concerning the link between ultra-loose monetary policies and nominal wage repression for growing parts of the populations see Schnabl (2016). This process is currently temporarily interrupted in Germany.

11 As for instance in the case of German hyperinflation of the early 1920s.

12 The paper does not discuss if the heterogeneous European Monetary Union can function. According to the literature on optimum currency areas (e.g. Mundell 1961), labor market flexibility and labor mobility are necessary to make a heterogeneous monetary union work. Vaubel (1978) added institutional proximity: countries that are close with respect to their policy paradigms are best equipped to run a successful currency union. If this is not the case and if the ECB's monetary policy is not in line with the country's original and traditional monetary policy, other policies must be adjusted. Whereas this may well work in a period of growth and full employment, it may be challenged in times of crisis. From this point of view, ultraexpansionary monetary policy can be seen as an attempt to keep a dysfunctional monetary union together.

13 Interest rates were cut strongly during crisis, whereas being not lifted to the same degree during the recovery (Hoffmann and Schnabl 2011). 
harmonized consumer price index in all parts of the European Monetary Union. In sharp contrast, prices of single segments of financial markets have increased dramatically with the ECB remaining passive. In phases of rising stock, real estate and commodity prices the large central banks have been mainly inactive, claiming that financial market prices are not in the responsibility of central banks. In contrast, they have strongly responded to sharply declining asset $_{\text {prices. }}{ }^{14}$

The resulting implicit insurance mechanism against losses from declining asset prices in the face of crisis created the breeding ground for new and even larger speculation booms in other segments of international financial markets (Hoffmann and Schnabl 2011). The resulting gradual inflation of central bank balance sheets has undermined the general trust in the currency as a store of value as represented by sharply increasing and fluctuating stock, gold and real estate prices. Phases of boom and bust in financial markets have created a high degree of uncertainty, which has become an impediment to investment and growth (see section 4).

Constitutive principle 3 stressed the need for open markets, where competition among a large number of small players works. This principle aimed at low tariffs and other trade restrictions including the exclusion of any form of anticompetitive government interventions. This should ensure allocation efficiency by bringing the production structure in line with consumer preferences. In addition, dynamic efficiency should be enhanced, as only a high intensity of competition was assumed to provide an incentive to enterprises to create temporary monopolistic rents by innovation. The imitation process following innovation should ensure incentives to generate a continuous stream of welfare enhancing innovation. ${ }^{15}$

Although the world economy has achieved a high degree of international trade liberalization and thereby competition in global goods markets (in particular for industrial goods), the convergence of interest rates towards zero and the inflation of central bank balance sheets has favored a concentration process in the enterprise sector for two reasons. First, the deprecations of the currencies following expansionary monetary policy impulses created windfall profits for export-oriented enterprises. Large enterprises tend to be more export-oriented than medium and, in particular, small enterprises.

\footnotetext{
${ }^{14}$ See Blinder and Reis (2005) on the so-called Jackson Hole Consensus.

15 See also the notion of Competition as a Discovery Procedure by Hayek (1968).
} 
Second, the ultra-loose monetary policies changed the financing conditions for large and small enterprises in an uneven way. Because large enterprises have direct access to capital markets they could refinance directly at gradually improving conditions. Small and many medium-sized enterprises remained, however, dependent on bank credit. Because in the course of the monetary policy rescue measures the banking sector is increasingly damaged, which leads to a concentration process, the financing conditions of small and medium enterprises deteriorated relative to large enterprises (Gerstenberger and Schnabl 2017). This implies that ultra-low interest rate policies trigger a concentration process in the enterprise and banking sector.

Constitutive principle 4 called for private ownership to ensure incentives to strive for profits and thereby for innovation and efficiency. Eucken (1952) stressed that private ownership has to come along with competition among enterprises. Otherwise private monopolies would encourage the misuse of market power at the cost of consumer welfare. Private ownership was regarded as particularly important by Ordoliberalism, because the planning economy in Eastern Germany had made the efficiency losses from state-ownership visible. Kornai (1993) characterized the situation in the central and eastern European economies as soft budget constraints: unprofitable enterprises were kept alive by credit provision of the state-owned banking sector to avoid the emergence of unemployment. As savings at state-owned banks were not large enough to cover the financing needs of enterprises, the funds were created by the central bank via the printing press thereby undermining the constitutive principles one and two.

Although, at a first glance, private ownership seems still warranted in all industrialized countries, the low, zero and negative interest rate policies have created quasi soft-budget constraints. While in the first phase low interest rate policies stimulate unsustainable credit growth, investment and financial speculation (Hoffmann and Schnabl 2011), the bursting of the bubbles makes overinvestment visible and creates bad loans. Interest rate cuts in response to bursting bubbles stabilize - in the short term - the financial sector and economic activity, because the decline of asset prices and therefore the stock of bad loans are contained. Yet, in the long term a quasi-nationalization process undermines private ownership and paralyzes growth (see section 4). 
Constitutive principle 5 stipulates the freedom of contract as a prerequisite for the economic order. Freedom of contract should remain, however, restricted to the extent that perfect competition was given. Freedom of contract seems principally still the case in the industrialized countries, but growing regulation, for instance in financial and labor markets, interferes with this principle. Given that expansive monetary policy has several side effects such as undue credit growth, real estate bubbles, nominal wage repression and precarious employment for growing shares of the population (Hoffmann and Schnabl 2016), the regulative response in form of intervention spirals gradually restricts the freedom of contract.

For instance, the unsustainable credit growth in Southern and Western Europe prior to the European financial and debt crisis as well as the subprime boom prior to the US subprime crisis has led to dramatic bad loan problems in the European and US-banking systems. To prevent a similar financial meltdown in the future, reporting requirements and financial supervision have been substantially extended. The higher density of financial regulation narrows, however, the freedom of contract in the financial sector. Similarly, as low-cost liquidity provision has driven-up real estate prices and thereby rents for new rental contracts, new regulations aim to contain rising rents. Further, in labor markets, as wages for new contracts are repressed and precarious employment forms flourish, minimum wages and regulations of minimum length of wage contracts aim at counter-steering this trend.

Constitutive principle 6 formulated the liability principle with a focus on the corporate sector. Enterprises are allowed in market economies to privatize profits as an important incentive for achieving efficiency and pushing forward innovation. At the same time, they are obliged to cover losses. The liability principle was intended to promote responsibility of the management towards a foresighted selection of investment projects. Eucken (1952) regarded stock holders to be liable for losses of enterprises and banks.

Since the mid 1980s, however, during financial crises the liability principle was increasingly hollowed out in two ways. First, collapsing financial institutions were bailed out with taxpayers' money to maintain the stability of the financial system as a whole. Bailouts could occur in form of recapitalizations or nationalizations of collapsing financial institutions. Furthermore, the take-over of insolvent banks by competitors, which is moderated by government, can be seen as a kind of hidden bail-out. ${ }^{16}$

\footnotetext{
16 In Japan, this procedure was dubbed convoy principle (Shimizu 2000).
} 
Second, more indirectly asymmetric interest rate policies and the gradual expansion of balance sheets are equivalent to a circumvention of the liability principle. During financial market boom-phases central banks do not steer against financial market exuberance, allowing the management of financial institutions to privatize windfall profits in form of high salaries and bonus payments. During crisis, however, the (potential) losses of financial institutions are prevented by sharp interest rate cuts, with the (potential) losses of financial institutions being socialized via the effects of monetary expansion. With inflation remaining low despite unprecedented monetary expansion, the costs of monetary financial stabilization measures increasingly have been showing up in declining interest rates on bank deposits and government bonds as well as in nominal wage repression for newcomers in the labor market (see Schnabl 2016).

Constitutive principle 7 , the principle of continuity of economic policy postulated that economic policy should be reliable and predictable for market participants. The notion behind this principle was that investment is strongly dependent on the predictability of future revenues. Price stability facilitates forecasting future profits and therefore reduces transaction costs. In addition, erratic economic policy making was seen to limit competition, as the signaling function of prices is disturbed, which was regarded as an impediment to investment and growth.

Monetary policy rescue measures have undermined the continuity principle via financial markets in two ways. First, as the gradual monetary expansion has increased the likelihood of financial market bubbles and thereby has amplified the amplitude of the business cycles. As Borio (2014) puts it, the global business cycle seems to be driven by the global financial cycle. Exuberant booms, which are characterized by sharply rising asset prices, flourishing profits of banks and enterprises, growing wages and affluent tax revenues are followed by dramatic crises and threatening financial meltdowns. Second, monetary rescue measures help to prevent the big crashes thereby stabilizing growth in the long term. But the growing scale of monetary policy rescue measure implies growing unintended side effects and thereby accelerating intervention spirals.

Constitutive principle 8 stressed that if only all principles were fulfilled together, market forces could enfold their full power to promote investment, growth and welfare. If only one principle would be undermined this could interfere with the intended effects of others. For 
instance, if the principle of private ownership is fulfilled, but monopolies persist, this allows the monopolist to privatize monopolistic profits reducing the welfare of consumers. Similarly, volatile inflation resulting from a bad monetary policy has a negative impact on labor markets, as real wages are reduced, with wages no longer reflecting scarcities in labor markets. Unemployment emerges.

Today a similar case can be made with respect to the bail-in mechanism of the European banking union. ${ }^{17}$ At a first glance, the bail-in procedure aims to restore the liability principle, because losses of banks are to be borne by shareholders and creditors instead of the tax payer. The mechanism intends in case of financial crisis to release the government from recapitalizations of financial institutions and/or central banks from monetary policy rescue measures. Yet, if at the same time an ultra-expansionary monetary policy persists (which hurts principles 1 and 7), the banking sector is damaged. The reason is that monetary policy rescue measures undermine the banks traditional source of income, i.e. the spread between lending and deposit rates (Gerstenberger and Schnabl 2017). In this case the bail-in procedure shifts the collateral damage of monetary rescue measures to the owners and creditors of banks. This erodes the constitutive principle of private ownership.

\section{Effects on Growth, Distribution and Political Stability}

The constitutive principles for market economies of Eucken (1952) aimed at creating an economic order with monetary stability being a prerequisite for investment, growth, welfare and social cohesion. Given that Eucken's (1952) constitutional principles unleased an economic miracle, Germany took over the role of an export-driven growth engine in post-war Western Europe. The high growth facilitated the delegation of power to the supra-national institutions in the course of the European integration process and came along with a high degree of political stability. The gradual erosion of Eucken's (1952) constitutive principles by monetary policy crisis management has undermined both the German and the European growth model for three reasons.

17 See: http://europa.eu/rapid/press-release_IP-15-6397_en.htm. 


\subsection{Negative Growth Effects}

First, the low costs liquidity provision has contributed to the decline of the marginal productivity of investment, because the allocation function of the interest rate has been undermined (Hoffmann and Schnabl 2016). In the neoclassical growth theory, growth originates in the accumulation of capital towards a long-term equilibrium between investment and depreciation (Solow 1956, Swan 1956). This steady state is based on the assumption that the marginal efficiency of capital declines, when the capital stock increases. Growth beyond this steady state is only possible, when innovation (i.e. technological progress) takes place, which ensures productivity growth in the long term (Solow 1957).

In such a neoclassical framework, low interest rates and quantitative easing have a negative impact on innovation and productivity gains, because incentives for innovation and efficiency gains are subdued. ${ }^{18}$ Sekine, Kobayashi and Saita (2003) find for Japan forbearance lending: Banks continue to provide irrecoverable loans to keep themselves and (potentially) insolvent companies alive. Similarly, Peek and Rosengren (2005) associate Japan's central bank crisis management with a misallocation of capital via the credit sector, which keeps companies with poor profit prospects alive ("evergreening"). The result is quasi-soft budget constraints as enterprises and banks remain dependent on the low-cost liquidity provision of the central bank.

Quian and Xu (1998) showed for China that such soft-budget constraints made it harder to separate profitable from unprofitable projects as the selection mechanism of the market was undermined. Caballero, Hoshi and Kashyap (2008) argued for Japanese - what they call "zombie-companies" that under zero interest rate policies profits have become dependent on cheap central bank liquidity provision via "zombie banks". The outcome has been a quasinationalization of the banking and enterprise sectors, as unconventional monetary policies have been continuing and are expected to continue over a long-time period.

Leibenstein (1966) sees motivation and incentives as major determinants of a dynamic concept of efficiency, which goes beyond static allocation efficiency. Enterprises do not realize all possible efficiency gains when competition is limited or alternative windfall profits are generated. Such X-inefficiency can be created by low interest policies and quantitative

18 Summers (2014) as well as Laubach and Williams (2015) assume in contrast that the gradual decline of interest rates is due to exogenous factors such as a structurally declining marginal efficiency of investment and ageing societies in the industrialized countries. 
easing, because financing costs are gradually reduced. ${ }^{19}$ Over the course of time the European Central Bank has cut the costs for financing via bank credit and the capital market. Given that asymmetric monetary policy has also inflated stock prices, costs of equity have structurally declined as well. Assuming that the expected return of an enterprise is constant, growing profits resulting from cheaper financing costs reduce the pressure to generate profits from innovation and efficiency gains.

Second, the monetary policy crisis management of the European Central Bank has affected banks and enterprises in different ways contingent on the size. Large enterprises can be assumed to have gained more than medium and small enterprises, because they have direct access to capital markets via bond financing and the emission of stocks. In addition, as large enterprises tend to be more export-oriented than small and medium enterprises, they have profited more from the depreciation effects of ultra-low interest rate policies and quantitative easing.

In contrast, small and medium enterprises remain dependent on bank financing. With banks being increasingly damaged by central bank crisis management ${ }^{20}$, also their ability to provide credit to small and medium enterprises has been restrained. This is even more the case, if outstanding credit to inefficient enterprises is prolonged. Then, credit conditions for new, more profitable investment projects are tight. The outcome is a concentration process in the enterprise sector, which is accelerated, if stock market booms go along with exuberance in the markets for mergers and acquisitions. The concentration process in the enterprise sector comes inevitably along with a declining degree of competition.

By tying resources to sectors with low or negative productivity gains (as distorted economic structures are conserved) or by reducing the degree of competition because of an increasing degree of concentration in the economy, in the context of the Solow-Swan model a negative allocative effect is created by declining average productivity (defined as output per unit of labor). Less goods and services are produced with a constant amount of labor. Since declining output also entails a decrease in savings per worker, an additional negative growth effect is the result, because households make fewer savings available for investment. Declining levels of household savings have been observed in all large industrialized countries, because private savings have been discouraged by declining deposit rates (Schnabl 2016). The result is from

\footnotetext{
19 Borio et al. (2016) show the negative impact of credit booms on the allocation of labor of labor in different sectors and their productivity levels.

20 The impact of low interest rate policies on the banking sector is analyzed by Gerstenberger and Schnabl (2017).
} 
Eucken's (1952) point of view declining investment, shrinking productivity gains and sluggish growth as it is observed in all large industrialized countries and as shown in Figure 2 for Germany.

Figure 2: Investment, Productivity Growth and Real Growth in Germany

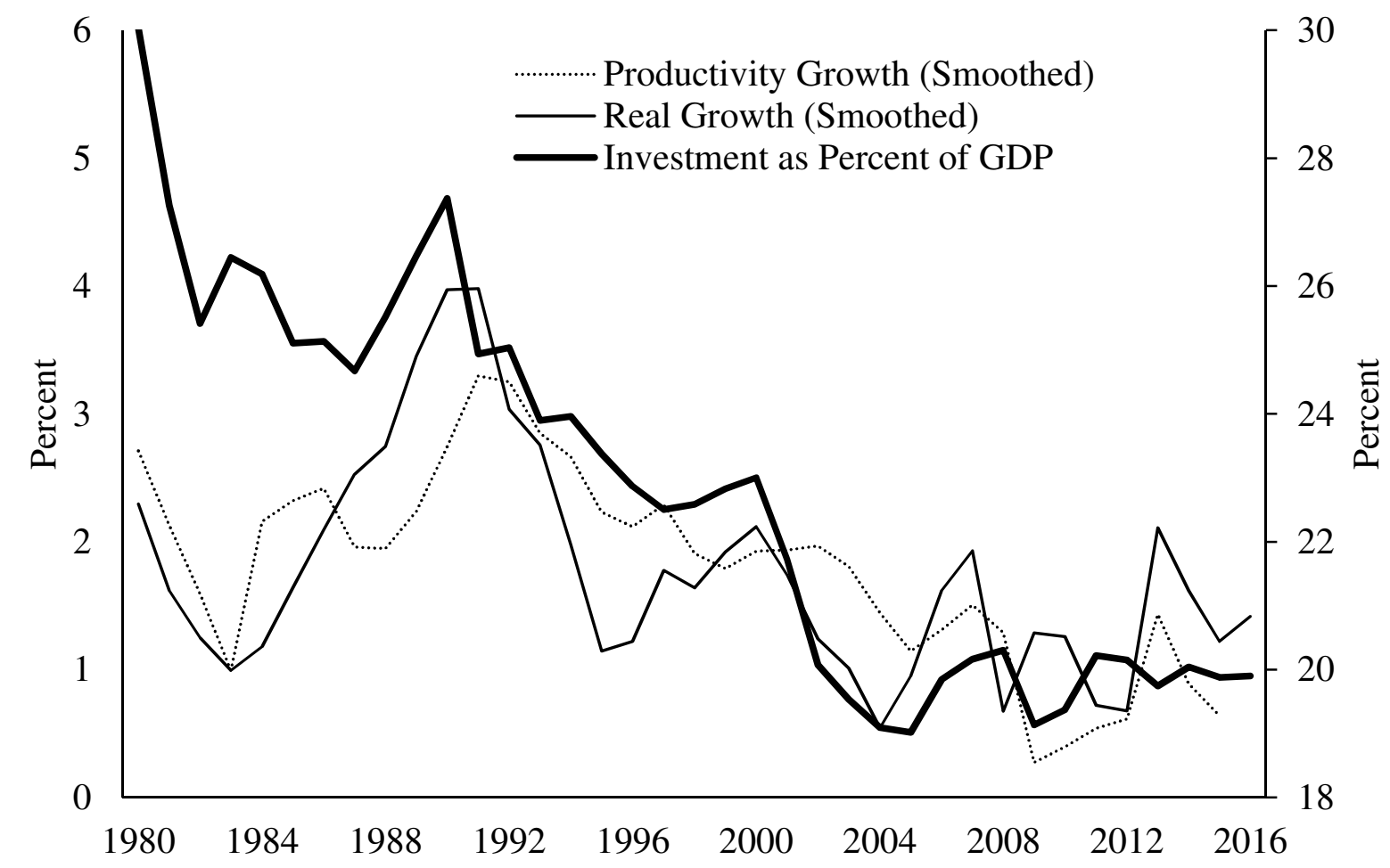

Source: OECD, Cabinet Office (Japan), BEA, Eurostat. Investment as percent of GDP.

The ultra-expansionary monetary policy is becoming persistent, because any increase of interest rates by the European Central Bank would force European governments to tighten expenditures, because the burden resulting from interest rate payments on public debt would strongly increase. Even in Germany, the growth of debt service would interfere with the large expenditure obligations, which have been created based on the regulative principles, i.e. extensive expenditures linked to social security, environment protection and efforts to ensure the cohesion of the European (Monetary) Union. With other words the regulative principles seem to have become the gateway for the destruction of the constitutive principles. $^{21}$

\footnotetext{
21 Similarly, Vanberg (2002) argues that the irenic formula, which should reconcile market principles with social justice in form of the social market economy also constituted the gateway for growing interventionism.
} 


\subsection{Effects on Income Equality}

Third, productivity growth is a prerequisite for real wage growth. With productivity growth converging towards zero, also the scope for the real wage increases become small. If under these circumstances monetary policy has redistribution effects towards specific groups, other groups inevitably loose. Cantillon (1931) stressed the redistribution effects of monetary expansion in favor of the financial system. If money supply is expanded by the central bank, the commercial banks not only benefit from accelerating credit growth. They can also purchase real estate, stocks and securities etc. at still constant prices. If the sellers of these assets use or provide the received funds for new purchases in these asset classes, real estate, stock and security prices have already increased. The result is a redistribution in favor of the financial sector. This redistribution is further enhanced if during the financial crisis, the decline of asset prices is prevented by monetary policy rescue measures.

From a more general perspective, if asset prices are influenced by the central banks in an asymmetric way, i.e. being pushed up by low-cost liquidity provision both during the boom and during the crisis, the agents holding large shares of these asset classes gain. This is usually the richer part of the population, which is intertwined with the high-income classes. For instance, the share of the top $1 \%$ income class out of total income in the United States has increased since the advent of asymmetric monetary policies in the mid 1980s from around $10 \%$ to currently around $22 \% .^{22}$

Given that asymmetric monetary policies have inflated real estate prices in most major industrialized economies, a wedge is driven into the societies via the real estate markets. Whereas incomes of young people entering the labor market have tended to stagnate or to decline compared to the elder generations, real estate prices have strongly increased. Since an increasing share of young people work in precarious employment forms they have a lower likelihood to have sufficient collateral for low-interest real-estate financing. In contrast the elder generations, which have acquired real estate earlier, profit from substantial revaluation gains. At the same time, wages of the elder generations remain at a high level as their wage contracts still allow bargaining for wage increases. Their expenditures for rents are contained by administrative rent controls. In contrast, rents for the younger generation increase.

The upshot is that moving up the social ladder - for instance from the dishwasher to millionaire - has become difficult. Wealth can be only built if it is inherited. Social cohesion as one basic regulative principle of the social market economy is undermined. Müller-Armack

\footnotetext{
22 Source: World Income Database. See also Hoffmann and Schnabl (2016).
} 
(1966: 243) had stressed that the market principles had to be combined with social balance. ${ }^{23}$ He defined three dimensions of the social state: the market forces, Ordnungspolitik, and redistribution. Whereas redistribution has reached an unprecedented dimension in Germany and other European countries, financed by high tax revenues and hidden government financing via the central banks, ${ }^{24}$ the first two dimensions of Müller-Armacks' (1966) social balance are increasingly put into question.

The positive social consequences of the market itself, which achieves high growth via static and dynamic efficiency, has been undermined in a dramatic way by monetary policy crisis management as productivity gains are subdued. The economic structure is decreasingly determined by consumer preferences, but increasingly by the political decisions about the allocation of funds collected via taxes and government bond purchases of the central bank. Major goals of Ordnungspolitik, for instance price stability and competition, have been gradually undermined, thereby questioning the social cohesion due to the far-reaching redistribution effects of ultra-low interest policies. The growing wedge in the German society is - like in many other industrialized countries - the breeding ground for growing dissatisfaction, in particular in the middle class. As a consequence, the political landscape is increasingly polarized. The political parties, which have been the basic stabilizing pillars of the German social market economy, continue losing stake.

\section{Wither "Social Market Economy"?}

It has been argued, that the very expansionary monetary policy of the European Central Bank is at odds with the constitutive principles of the social market economy including goals such as social cohesion and political stability. The German market economy is increasingly dysfunctional, since price signals on capital markets are distorted. The principle of open markets is under stress, since the ECB's monetary policy has two negative effects: it supports

23 „Sinn der Sozialen Marktwirtschaft ist es, das Prinzip der Freiheit auf dem Markte mit dem des sozialen Ausgleichs zu verbinden. ... Der Begriff der Sozialen Marktwirtschaft kann als eine ordnungspolitische Idee definiert werden, deren Ziel es ist, auf der Basis der Wettbewerbswirtschaft die freie Initiative mit einem gerade durch die marktwirtschaftliche Leistung gesicherten sozialen Fortschritt zu verbinden." MüllerArmack (1966: 243-245). The postulate of Müller-Armack was seen to be based on the German constitution, which forsees in articles 20 and 28 that the Federal Republic of Germany is a democratic and social federal state. Art. 20, first paragraph: "Die Bundesrepublik Deutschland ist ein demokratischer und sozialer Bundestaat.” Art. 28, first paragraph: „Die verfassungsmäßige Ordnung in den Ländern muss den Grundsätzen des republikanischen, demokratischen und sozialen Rechtsstaates (...) entsprechen."

24 For instance, roughly one third of the budget of the German central government are spent for social security purposes. 
large firms and banks at the expense of small ones and sets incentives against innovation and efficiency gains thereby paralyzing growth. Governments get addicted to low interest rates, time does not have a price anymore, sustainable fiscal policy is no longer politically attractive.

As a side effect, small and efficient banks are under threat, so that they do not grant fresh credits for young firms. Instead, zombie banks are financing zombie firms. This prevents innovation and structural change, which would be urgently needed to create new jobs and economic growth. As the negative incentives of low interest rate policy on private investors puts increasing pressure on governments to create employment via public demand and economic nationalism, the freedom of contract as well as competition continue to diminish. In line with Hayek (1944) the gradual loss of economic freedom seems to be followed by a gradual loss of political freedom with the political landscape being increasingly polarized.

In particular, the social and political consequences of the very expansive monetary policies should be reason enough to exit from the very expansionary monetary policy better sooner than later. As central banks continue to drive a wedge between the old and the young as well as between the rich and the poor, the social cohesion, which has been one of the main goals of the German social market economy, is at risk. This is also the case for the partner countries in the European Union, because the redistribution effects of the ECB`s monetary policy are similar in all member states of the European Union. Furthermore, if growth in Germany is paralyzed, also growth in whole Europe is declining.

Therefore, the timely exit from ultra-expansionary monetary policy is recommended. Asset purchases of the European Central Bank should be phased out in a timely manner and interest rate increases should take place at a slow pace to facilitate adjustment, but in a decisive way. This would force over-indebted governments to push forward structural reforms. Banks would have to clean up their bad loans and to reconstitute their traditional business model of financing investment projects with high excepted returns. This would necessitate enterprises to intensify efforts for innovations and efficiency gains. The resulting increase in productivity gains would make real wage increases possible again, which would contribute to a political stabilization in Europe. This is in the very interest of all European citizens. 


\section{References}

Blinder, Alan / Reis, Ricardo (2005): Understanding the Greenspan Standard. Mimeo.

Böhm, Franz (1950): Die Idee des ORDO im Denken Walter Euckens. Dem Freund und Mitherausgeber zum Gedächtnis. In: ORDO 3, 15-64.

Borio, Claudio (2014): The Financial Cycle and Macroeconomics: What Have We Learnt? Journal of Banking and Finance 45, 182-198.

Borio, Claudio / Kharroubi, Enisse / Upper, Christian / Zampolli, Fabrizio (2016): Labour Reallocation and Productivity Dynamics: Financial Causes, Real Consequences. BIS Working Papers 534.

Caballero, Ricardo / Hoshi, Takeo, / Kashyap, Anil (2008): Zombie Lending and Depressed Restructuring in Japan. American Economic Review 98, 5, 1943-1977.

Cantillon, Richard (1931): Abhandlung über die Natur des Handels im allgemeinen. Jena.

Deutsche Bundesbank (2016): What is to Become of Our Money, Mr Weidmann? Interview published in Frankfurter Allgemeine Sonntagszeitung, 11.12.2016. https://www.bundesbank.de/Redaktion/EN/Interviews/2016_12_11_weidmann_fas.html

Eucken, Walter (1952): Grundsätze der Wirtschaftspolitik. Tübingen and Zürich: Mohr Siebeck and Polygraphischer Verlag.

Freytag, Andreas (2002): Success and Failure in Monetary Reform. Cheltenham and Northhampton, MA.: Edward Elgar.

Gerstenberger, Juliane / Schnabl, Gunther (2017): The Effects of Unconventional Monetary Policy on the Japanese Banking Sector. Mimeo.

Gertler, Pavel / Hofmann, Boris (2016): Monetary Facts Revisited. BIS Working Papers 566.

Hayek, Friedrich August von (1931): Prices and Production. New York: August M. Kelly Publishers.

Hayek, Friedrich August von (1944): The Road to Serfdom. Chicago: University of Chicago Press.

Hayek, Friedrich August von (1945): The Use of Knowledge in the Society. American Economic Review 35, 4, 519.530.

Hayek, Friedrich August von (1968): Der Wettbewerb als Entdeckungsverfahren. In: Internationales Institut „Österreichische Schule der Nationalökonomie" (eds): Die Österreichische Schule der Nationalökonomie. Texte - Band II von Hayek bis White. Wien: Manz'sche Verlags- und Universitätsbuchhandlung, 119-137. 
Hoffmann, Andreas / Schnabl, Gunther (2011): A Vicious Cycle of Manias, Crises and Asymmetric Policy Responses - An Overinvestment View. The World Economy 34, 382403.

Hoffmann, Andreas / Schnabl, Gunther (2016): The Adverse Effects of Ultra-Loose Monetary Policies on Investment, Growth and Income Distribution. Cato Journal 36, 3, 449-484.

Hoppmann, Erich (1968): Zum Problem einer wirtschaftspolitisch praktikablen Definition des Wettbewerbs. In: Schneider, Hans (Hrsg.): Grundlagen der Wettbewerbspolitik. Berlin: Duncker \& Humblot, 9-49.

Kantzenbach, Erhard (1966): Die Funktionsfähigkeit des Wettbewerbs. Göttingen: Vandenhoeck \& Ruprecht.

Kornai, János (1986): The Soft Budget Constraint. Kyklos 39 1, 3-30.

Laubach, Thomas / Williams, John (2015): Measuring the Natural Rate of Interest Redux. Federal Reserve Bank of San Francisco Working Paper 2015-16.

Leibenstein, Harvey (1966): Allocative Efficiency vs. X-Efficiency. American Economic Review 56, 3, 392-415.

Lucas, Robert (1976). Econometric Policy Evaluation: A Critique. Carnegie-Rochester Conference Series on Public Policy 1, 19-46.

Marx, Reinhard (2006): Wirtschaftsliberalismus und Katholische Soziallehre. Freiburg Discussion Papers on Constitutional Economics 06/3.

Miksch, Leonhard (1937): Wettbewerb als Aufgabe: die Grundsätze einer Wettbewerbsordnung. Stuttgart: Kohlhammer.

Müller-Armack (1950/1982): Social Irenics. In: Stützel, Wolfgang / Watrin, Christian / Willgerodt, Hans / Hohmann, Karl (eds.): Standard Texts of the Social Market Economy. Stuttgart and New York: Gustav Fischer, 347-359.

Müller-Armack (1966): Wirtschaftsordnung und Wirtschaftspolitik: Studien und Konzepte zur sozialen Marktwirtschaft und zur europäischen Integration. Rombach und Freiburg: Haupt.

Mundell, Robert (1961): Optimum Currency Areas. American Economic Review 51, 4, 717 724.

Muresan, Stefan (2014): Social Market Economy. The Case of Germany. Cham et al.: Springer.

North, Douglass (1990): Institutions, Institutional Change and Economic Performance. Cambridge: Cambridge University Press.

Peek, Joe / Rosengren, Eric (2005): Unnatural Selection: Perverse Incentives and the Misallocation of Credit in Japan. American Economic Review 95, 4, 1144-1166.

Quian, Yingyi / Xu, Chenggang (1998): Innovation and Bureaucracy under Soft and Hard Budget Constraints. Review of Economic Studies 65, 1, 151-164. 
Schnabl, Gunther (2016): Central Bank Crisis Management from an Austrian Business Cycle Perspective. CESifo Working Paper 6179.

Sekine, Toshitaka / Kobayashi, Keiichiro / Saita, Yumi (2003): Forbearance Lending: The Case of Japanese Firms. Bank of Japan Institute for Monetary and Economic Studies 21, 2, 69-92.

Shimizu, Yoshinori (2000): Convoy Regulation, Bank Management and the Financial Crisis in Japan. In: Mikitani, Ryoichi and Posen, Adam (eds.): Japan's Financial Crisis and Its Parallels to U.S. Experience, Institute for International Economics, Washington D.C., 5799.

Solow, Robert (1956): A Contribution to the Theory of Economic Growth. Quarterly Journal of Economics 70, 1, 65-94.

Solow, Robert (1957): Technical Change and the Aggregate Production Function. Review of Economics and Statistics 39, 2, 312-320.

Starbatty, Joachim (1984): Ordoliberalismus. In: Issing, Otmar (ed.): Geschichte der Nationalökonomie. München: Vahlen, 239-254.

Summers, Larry (2014): U.S. Economic Prospects: Secular Stagnation, Hysteresis, and the Zero Lower Bound. Business Economics 49, 2, 65-73.

Swan, Trevor (1956): Economic Growth and Capital Accumulation. Economic Record 32, 2, 334-361.

Tinbergen, Jan (1952): On the Theory of Economic Policy. North Holland: Amsterdam.

Vaubel, Roland (1978): Strategies for Currency Unification: the Economics of Currency Competition and the case for a European Parallel Currency. Kiel: Kieler Studien 156.

Vanberg, Victor (2002): Soziale Sicherheit, Müller-Armacks "Soziale Irenik" und die ordoliberale Perspektive. In Hasse, Rolf / Quaas, Friedrun (eds.): Wirtschaftsordnung und Gesellschaftskonzept. Bern: Haupt, 227-260.

Vanberg, Viktor (2015): Ordoliberalism, Ordnungspolitik, and the Reason of Rules. European Review of International Studies 2, 3, 7-36.

Williamson, John 2000: What Should the World Bank Think About the Washington Consensus? World Bank Research Observer 15, 2, 251-261. 